\title{
Does Accreditation Symbolize Quality in Public Healthcare Delivery? An Investigation of Hospitals in Kerala
}

Sindhu Joseph, PhD

Address for correspondence:

Department of Travel and Tourism Management

GPM Government College, Manjeshwar, Kasaragod, Kerala, India

PIN: 671323

Email: sjsindhu@gmail.com 


\section{Abstract}

Accreditation has become an important benchmark for healthcare organisations, and accordingly, many government hospitals in Kerala got accredited with national level $(\mathrm{NABH})$ and state level $(\mathrm{KASH})$ accreditation programmes. This study examined the quality of public healthcare delivery in these accredited hospitals while having a comparison with the non-accredited hospitals. It also compared the impact of national and state-level accreditation programmes in Kerala public healthcare settings. This crosssectional study conducted between July 2017 and July 2018, employing a positivist approach using stratified random sampling. In total, 621 samples were collected from inpatients of both accredited (NABH and $\mathrm{KASH}$ ) (312) and nonaccredited (309) public healthcare institutions in Kerala. Nine constructs overarching the quality of healthcare delivery and patient satisfaction construct are used in the study. The study found that patient satisfaction is identical in both accredited and nonaccredited hospitals ( $M=4.28)$. Patient satisfaction in NABH accredited hospital $(M=4.27 \pm 0.67874)$ is lower than that of $\mathrm{KASH}$ accredited hospital $(\mathrm{M}=4.30 \pm 1.25417)$. The mean score of six constructs of quality healthcare delivery of KASH accredited hospitals is higher than NABH accredited. Thus, the study concluded that accreditation, regardless of its type, has no impact on patient satisfaction even though the accreditation process slightly improved different dimensions of quality healthcare delivery.

Key Words: Accreditation; Healthcare quality; Patient satisfaction, Accredited and nonaccredited; $\mathrm{NABH}, \mathrm{KASH}$. 


\section{INTRODUCTION}

Internationally, since the 1970 s, healthcare accreditation programs and accrediting organisations emerged and developed to enhance the healthcare quality improvement activities (Almoajel, 2012; World Health Organization, 2003). This process includes selfassessment and external peer assessment to assess their level of performance against established standards, protocols, laws and regulations. Accreditation demands commitment from the healthcare organisations to improve quality, patient safety, efficiency and accountability and, therefore, increases public acknowledgement (Pomey et al., 2005;Yousefinezhadi et al., 2020). This process measures quality of healthcare institution using a standardised tool which may include the details of qualification, experience and training of healthcare professionals, patient facilities, patient-staff ratios, and acceptance of medical insurance schemes.

There are programmes at international, national and state levels for accrediting hospitals like Joint Commission International ( $\mathrm{JCl})$, National Accreditation Board for Hospitals \& Healthcare Providers (NABH) in India and Kerala Accreditation Standards for Hospitals (KASH) in Kerala. NABH is founded by the Government of India in 2006 as a benchmark for excellence in healthcare to establish and operate accreditation programme for healthcare organisations. NABH is a constituent board of Quality Council of India (QCI), set up to establish and operate accreditation programme for healthcare organisations. The programme focuses on continuous quality enhancement in terms of patient safety and healthcare delivery based upon national/international standards and mandates to 
medRxiv preprint doi: https://doi.org/10.1101/2020.08.22.20170837; this version posted August 25, 2020. The copyright holder for this preprint (which was not certified by peer review) is the author/funder, who has granted medRxiv a license to display the preprint in perpetuity.

It is made available under a CC-BY-NC-ND 4.0 International license .

fulfil and operationalise a comprehensive list of $500+$ distinct features. Kerala is the first among the states of India to undergo NABH accreditation of its hospitals.

\subsection{Accreditation and healthcare of Kerala}

According to World Bank and Niti Aayog (India), the health indicators of Kerala are on par with the western countries, and the Kerala healthcare model is accepted globally(Kerala State Planning Board, 2017) especially after successfully managing the epidemic Nipah Fever and the pandemic COVID-19. There are 1,280 health institutions with 38,004 beds and 5,465 doctors under Health Services Department (DHS) consisting 848 Primary Health Centers(PHCs), 232 Community Health Centers(CHCs), 81 Taluk Head Quarters hospitals(THQH), 18 District Hospitals, 18 General hospitals(GHs) and eight Women \& Children(W\&C) hospitals (National Rural Health Mission, 2013;Maya, 2015). According to the minutes of the $11^{\text {th }}$ Executive Committee meeting of Kerala State Health and Family Welfare Society held on $14^{\text {th }}$ July 2010 , 'quality is a guiding principle' in assessing how well the health system is performing (National Rural Health Mission, 2013).

Kerala has the largest number of $\mathrm{NABH}$ accredited hospitals in India under the public sector (Maya, 2015). The new accreditation program, KASH, was introduced in the year 2012, as an initial level accreditation to enhance the quality of curative and preventive healthcare services with the state-of-the-art technology and implemented in selected PHCs, CHCs, THQHs and higher hospitals (National Rural Health Mission, 2013). In order to uplift the quality standards and services given by the public sector hospitals in all care settings, the criteria for $\mathrm{KASH}$ was developed in such a way that implementing the program is probable with a modest investment. After achieving $\mathrm{KASH}$, the hospitals may 
medRxiv preprint doi: https://doi.org/10.1101/2020.08.22.20170837; this version posted August 25, 2020. The copyright holder for this preprint (which was not certified by peer review) is the author/funder, who has granted medRxiv a license to display the preprint in perpetuity.

It is made available under a CC-BY-NC-ND 4.0 International license .

choose for higher accreditation standards like $\mathrm{NABH}$, which require more investment and effort (National Rural Health Mission, 2013).

\subsection{Quality and patient satisfaction in healthcare delivery}

Many researchers have made seminal contributions on service quality and resulting patient satisfaction. Accreditation Canada defines quality improvement (QI) as "the degree of excellence; the extent to which an organisation meets its clients' needs and exceeds their expectations" (Mondoux, Calder-Sprackman and Thull-Freedman, 2020, p.11). Previous studies have emphasised varied aspects to study the quality healthcare such as availability, accessibility, affordability, acceptability, appropriateness, competency, effective service delivery, privacy, state-of-the-art technology, care, physical environment, responsiveness, admission, treatment, patient-centeredness, waiting-time, cleanliness and hygiene, attitude of doctors and nurses, reliability, comprehensiveness, continuity and equity (Al Tehewy et al., 2009; Amin and Nasharuddin, 2013; Cheng, 2003; Joseph, 2012, 2016, 2017; Linder-Pelz, 1982; Mosadeghrad, 2014; Peprah, 2014; Saeed and Mohamed, 2002; Tashkandi, Hejazi, and Lingawi, 2017; Ware et al., 1983; Zineldin, 2006).

The outcome of quality healthcare delivery overarching the above dimensions is patient satisfaction. Studies on the above mentioned constructs are there in the international and Indian contexts (Banyai, 2012; Delgoshaei, Ravaghi, and Abolhassani, 2012; Grewal et al., 2012; Kavitha, 2012; Lin, 2004; Newcomer, 1997; Parasuraman et al., 1985; Powell, 2001; Saxena, 2009; Solayappan et al., 2011; Verlinde et al., 2012; Yeoh et al., 2013). Patient satisfaction is an essential factor for maintaining long-term relationships, reflected 
medRxiv preprint doi: https://doi.org/10.1101/2020.08.22.20170837; this version posted August 25, 2020. The copyright holder for this preprint (which was not certified by peer review) is the author/funder, who has granted medRxiv a license to display the preprint in perpetuity.

It is made available under a CC-BY-NC-ND 4.0 International license .

in revisits and willingness to recommend(Elleuch, 2008; Verlinde et al., 2012). LinderPelz (1982, p.14) defined patient satisfaction as an "individual's positive evaluation of distinct dimensions of healthcare." A well-designed patient satisfaction survey will combine these elements as it relates to the total patient experience(Powell, 2001).

\subsection{Impact of accreditation programmes}

There exists a considerable body of literature, establishing the positive impact of accreditation on quality enhancement (Andres et al., 2019; Schmaltz et al., 2011). Despotou et al.,( 2020), in a study among nurses in South Korea, found that accreditation has a positive impact on patient safety in tertiary care. Accreditation could bring continuity of quality patient care, and human resource management processes improved across time(Greenfield \& Braithwaite, 2009). Sheikh (2017) found that accreditation has a positive impact on the satisfaction of the pharmacy department in a private tertiary care hospital at Secunderabad, Telangana State, India. Similarly, Camillo et al., (2016) found that accreditation is a favourable system for quality management in the public service because it promotes the development of professional skills and improves cost management, organisational structure, management of assistance and perception of job pride/satisfaction. Accreditation is an interface that strengthens trust between medical institutions and patients, especially in undeveloped countries (Spasojevic and Susic, 2011). Williams et al., (2017) compared the quality ratings of accredited and nonaccredited nursing homes and found that accreditation is a significant predictor of quality enhancement.

Nonetheless, many studies established that accreditation was not associated with considerable improvement in healthcare delivery(Bogh et al., 2015; Lam et al., 2018; 
Rosenberg et al., 2016). Accreditation mainly emphasis on improving structural factors and clinical processes rather than improving patient outcomes. Al Otaibi, Kattan and Nabil, (2020) found the reverse effect of CBAHI (Saudi Central Board for Accreditation of Healthcare Institutions) on patient safety and failed to create total quality management.

Although there are many studies on accreditation structure, performance and patient satisfaction, the results are contradictory and inconclusive. A holistic comparative study of accreditation impact in public healthcare facilities using various quality dimensions is rare. Moreover, previous studies have almost focused exclusively on accredited hospitals with pre-test and post-test and measured the outcome without having a comparison group and vice versa. More importantly, there has been no previous evidence for studies comparing the effectiveness of national and state level accreditation programmes. In this context, this paper identifies nine dimensions of quality healthcare delivery and examines its impact on patient satisfaction (outcome) both in accredited (NABH and $\mathrm{KASH}$ ) and non-accredited public healthcare settings of Kerala. This study results will throw light into the impact of implementing national and state level accreditation programmes. To this end, the following two hypotheses are formulated and tested using appropriate statistical techniques.

1. Quality healthcare delivery enhances patient satisfaction in accredited hospitals in Kerala.

2. $N A B H$ accreditation creates more impact than $\mathrm{KASH}$ in various dimensions of quality healthcare delivery in Kerala. 
A conceptual framework is developed with ten latent constructs on the basis of the review of literature (see Figure 1).

\section{Fig.1 Conceptual Framework}

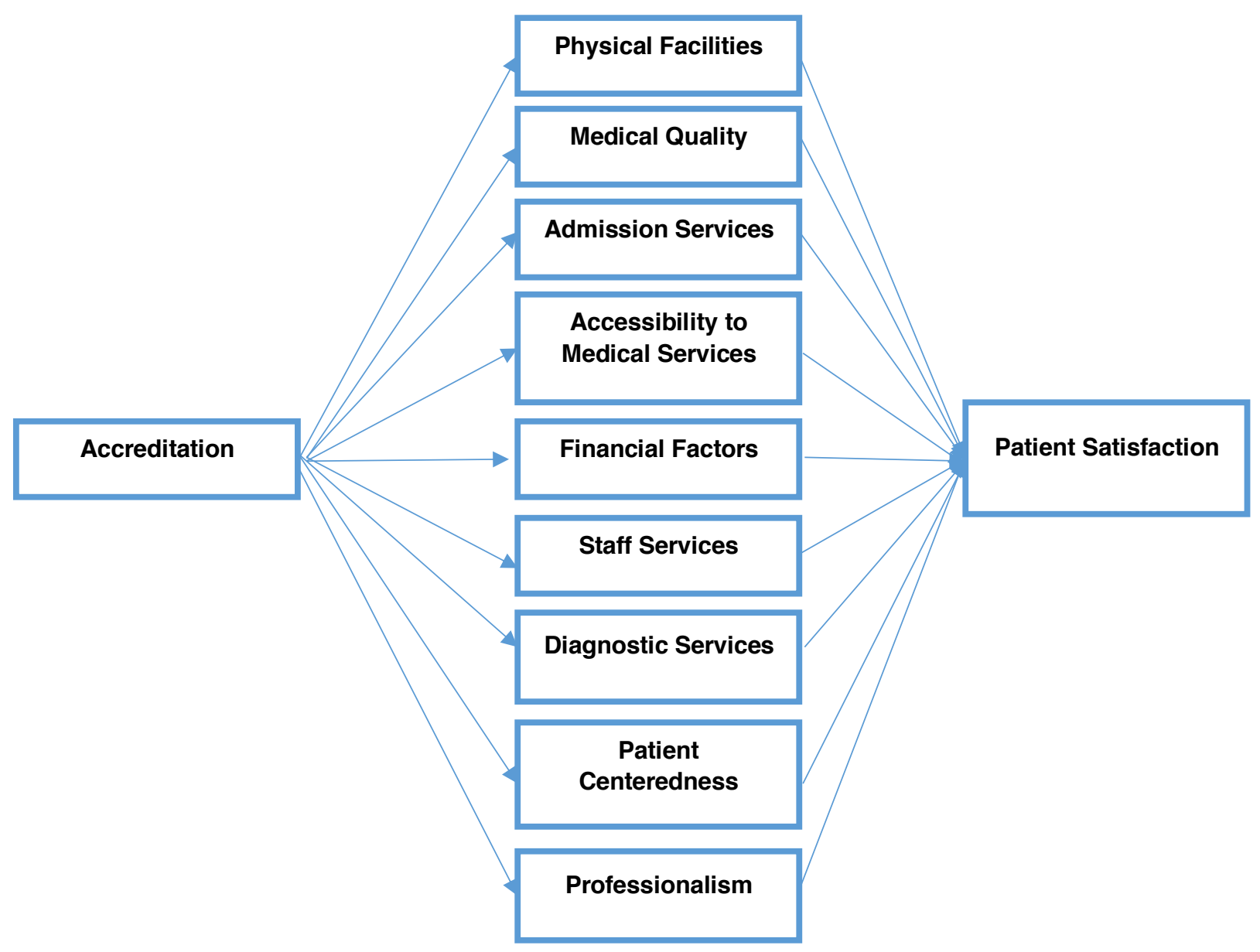

\section{METHODS}

It is a cross sectional study drew on a positivist approach. Kerala healthcare model functions through a three-tier system, and therefore, the research used stratified random sampling where four strata - GHs, W\&C hospitals, 'Taluk Hospitals' (THs)/THQHs and CHCs- are selected randomly from Southern, Central and Northern regions of Kerala. The study's target population was in-patients admitted to medical wards at public 
hospitals, both accredited and non-accredited. Informed consent was obtained from them after describing the nature of the survey and prior permission to collect data from IP wards was obtained from the Department of Health Services (DHS) Kerala. In-patients aged 16 years or older and able to speak Malayalam or English language were included in the study. Being primary care facilities, PHCs were excluded from the study due to the lack of an acceptable number of in-patients.

\section{Table 1. Sampling}

\begin{tabular}{|c|c|c|c|c|c|c|c|}
\hline \multicolumn{4}{|c|}{ Accredited Hospitals (NABH + KASH) } & \multicolumn{4}{|c|}{ Non-accredited Hospitals } \\
\hline $\begin{array}{l}\text { Hospital } \\
\text { Type }\end{array}$ & $\begin{array}{l}\text { Total } \\
\text { no. of } \\
\text { beds }\end{array}$ & $\begin{array}{c}\text { Strata } \\
\text { size }\end{array}$ & $\begin{array}{l}\text { Sample } \\
\text { size }\end{array}$ & $\begin{array}{c}\text { Hospital } \\
\text { Type }\end{array}$ & $\begin{array}{l}\text { Total } \\
\text { no. of } \\
\text { beds }\end{array}$ & $\begin{array}{l}\text { Strata } \\
\text { size }\end{array}$ & $\begin{array}{l}\text { Sample } \\
\text { size }\end{array}$ \\
\hline $\mathrm{CHC}$ & 6567 & $10 \%$ & 65 & $\mathrm{CHC}$ & 6567 & $10 \%$ & 65 \\
\hline $\mathrm{GH}$ & 6920 & $15 \%$ & 103 & $\mathrm{GH}$ & 6920 & $15 \%$ & 106 \\
\hline THQH/ TH & 8553 & $10 \%$ & 85 & $\mathrm{THQH} / \mathrm{TH}$ & 8553 & $10 \%$ & 85 \\
\hline W\&C & 5662 & $10 \%$ & 59 & W\&C & 5662 & $10 \%$ & 53 \\
\hline \multicolumn{3}{|c|}{ Total } & 312 & \multicolumn{3}{|c|}{ Total } & 309 \\
\hline
\end{tabular}

To get a valid number of samples, $10 \%$ of the number of beds from each stratum was included in the study except GHs (15\%) where there is only one GH accredited in Kerala (See Table 1). A total of 760 questionnaires were circulated in the In-Patient wards, of which $621(82 \%)$ were valid for analysis (312 from accredited and 309 from nonaccredited) which is considered sufficient to represent a large population Saunders, Lewis, and Thornhill, 2009).

This study was conducted from July 2017 to July 2018 using a questionnaire with 60 items covering ten constructs by adopting previous critical studies and models in the area(Amin 
medRxiv preprint doi: https://doi.org/10.1101/2020.08.22.20170837; this version posted August 25, 2020. The copyright holder for this preprint (which was not certified by peer review) is the author/funder, who has granted medRxiv a license to display the preprint in perpetuity. It is made available under a CC-BY-NC-ND 4.0 International license .

and Nasharuddin, 2013; Darwazeh, 2011; Joseph, 2012; Kang et al., 2012; Lam, 1997; Legido-Quigley et al., 2008; Mosadeghrad, 2012; Pai and Chary, 2016; Peprah, 2014; Tashkandi, Hejazi, and Lingawi, 2017; Zineldin, 2006). The five dimensions of SERVQUAL model (Tangibles, Reliability, Responsiveness, Assurance and Empathy) and the Donabedian's Structure- Process-Outcome (SPO) model are also imbibed in the chosen constructs. The first part of the questionnaire comprised of demographic information such as age, gender, educational level, marital status, employment status and the reason for hospital selection. The second section included statements to measure patients' opinion on healthcare received by them on a 5-point scale (1=Strongly Agree to $5=$ Strongly Disagree)(Gursoy \& Rutherford, 2004). The variables were grouped under ten constructs, namely Physical Facility (14 items), Admission Services (2 items), Patient centeredness (7 items), Accessibility of Medical Care (5 items), Financial Matters (5 items), Professionalism (4 items), Staff Services (4 items), Medical Quality (4 items), Diagnostic Services (2 items) and Patient Satisfaction ( 5 items). Initially the questionnaire was developed in the English language and then subsequently translated into Malayalam. Based on the result from the pilot test, slight changes were made in few questions. The validity of the questionnaire was evaluated based on content validity and expert opinion. The constructs wise Cronbach's Alpha value was higher than the guideline value of 0.6. Simple statistical techniques like descriptive statistics, t-test, and Kruskal Wallis tests have been undertaken for data analysis.

\section{RESULTS}

\subsection{Baseline socio-demographic variables}


Patients seek healthcare in government hospitals are mainly females, koolies (daily workers) and students and majority belong to < Rs. 5000 income group. The striking point is that, in accredited hospitals, only $2.2 \%$ of the patients are bothered about the accreditation status while choosing the hospital. 'Free treatment' is the dominant push factor for them (see Table 2).

Table. 2: Baseline socio-demographic variables

\begin{tabular}{|c|c|c|c|c|}
\hline \multirow[t]{2}{*}{ Variable } & \multicolumn{2}{|c|}{$\begin{array}{c}\text { Non-Accredited } \\
\text { Hospitals }\end{array}$} & \multicolumn{2}{|c|}{ Accredited Hospitals } \\
\hline & $\begin{array}{l}\text { Frequency } \\
(\mathrm{N}=309)\end{array}$ & $\%$ & $\begin{array}{c}\text { Frequency } \\
(\mathrm{N}=312)\end{array}$ & $\%$ \\
\hline \multicolumn{5}{|l|}{ Age } \\
\hline Below 18 & 27 & 8.7 & 7 & 2.2 \\
\hline $18-30$ & 122 & 39.5 & 112 & 35.9 \\
\hline $31-45$ & 85 & 27.5 & 68 & 21.8 \\
\hline $56-59$ & 50 & 16.2 & 56 & 17.9 \\
\hline $60-75$ & 22 & 7.1 & 53 & 17 \\
\hline Above 75 & 3 & 1.0 & 16 & 5.1 \\
\hline \multicolumn{5}{|l|}{ Gender } \\
\hline Male & 99 & 32 & 107 & 34.3 \\
\hline Female & 210 & 68 & 205 & 65.7 \\
\hline \multicolumn{5}{|l|}{ Marital Status } \\
\hline Married & 243 & 78.6 & 271 & 86.9 \\
\hline Unmarried & 66 & 21.4 & 40 & 12.8 \\
\hline \multicolumn{5}{|l|}{ Educational Level } \\
\hline Primary & 38 & 12.3 & 63 & 20.2 \\
\hline Upper Primary & 20 & 6.5 & 18 & 5.8 \\
\hline Secondary & 149 & 48.2 & 143 & 45.8 \\
\hline Degree & 101 & 32.7 & 77 & 24.7 \\
\hline \multicolumn{5}{|l|}{ Occupation } \\
\hline Government Sector & 19 & 6.1 & 15 & 4.8 \\
\hline Private Sector & 47 & 15.2 & 48 & 15.4 \\
\hline Koolie & 56 & 18.1 & 83 & 26.6 \\
\hline Student & 47 & 15.2 & 28 & 9 \\
\hline Unemployed & 140 & 45.3 & 136 & 43.6 \\
\hline \multicolumn{5}{|l|}{ Monthly Income } \\
\hline Below Rs.5000 & 215 & 69.6 & 216 & 69.2 \\
\hline
\end{tabular}




\begin{tabular}{|l|c|c|c|c|}
\hline $5,000-10,000$ & 65 & 21 & 77 & 24.7 \\
\hline $10,000-20,000$ & 20 & 6.5 & 17 & 5.4 \\
\hline 20,000 above & 8 & 2.6 & 2 & 0.6 \\
\hline Reason Choose the Hospital & 54 & 17.5 & 53 & 17 \\
\hline Quality Care & 155 & 50.2 & 107 & 34.3 \\
\hline Free Treatment & -- & -- & 7 & 2.2 \\
\hline National/ or state accreditation & 30 & 9.7 & 17 & 5.4 \\
\hline Facilities & 67 & 21.7 & 128 & 41 \\
\hline All of the above & & & & \\
\end{tabular}

\subsection{Dimensions of Quality Healthcare Delivery}

Table 3. Comparison of accredited vs non-accredited hospitals: t-test results for constructs of dimensions of quality healthcare delivery.

\begin{tabular}{|c|c|c|c|c|c|c|}
\hline \multirow[t]{2}{*}{ Constructs } & \multicolumn{6}{|c|}{ Dimensions of Quality Healthcare Delivery } \\
\hline & Status & Mean & SD & t- value & Df & p-value \\
\hline \multirow[t]{2}{*}{ Physical Facility } & Non-accredited & 4.00 & 0.9729 & \multirow[t]{2}{*}{-3.342} & \multirow[t]{2}{*}{619} & \multirow[t]{2}{*}{0.001} \\
\hline & Accredited & 4.26 & 0.9785 & & & \\
\hline \multirow[t]{2}{*}{ Admission Services } & Non-accredited & 4.27 & 2.1237 & \multirow[t]{2}{*}{-0.025} & \multirow[t]{2}{*}{607} & \multirow[t]{2}{*}{0.980} \\
\hline & Accredited & 4.27 & 0.8780 & & & \\
\hline \multirow[t]{2}{*}{ Patient Centeredness } & Non-accredited & 4.25 & 0.7405 & \multirow[t]{2}{*}{-2.386} & \multirow[t]{2}{*}{619} & \multirow[t]{2}{*}{0.017} \\
\hline & Accredited & 4.41 & 0.9061 & & & \\
\hline \multirow{2}{*}{$\begin{array}{l}\text { Accessibility of Medical } \\
\text { Services }\end{array}$} & Non-accredited & 3.68 & 0.9530 & \multirow[t]{2}{*}{-2.968} & \multirow[t]{2}{*}{619} & \multirow[t]{2}{*}{0.003} \\
\hline & Accredited & 3.93 & 1.1055 & & & \\
\hline \multirow[t]{2}{*}{ Financial Factors } & Non-accredited & 3.90 & 1.1313 & \multirow[t]{2}{*}{-0.595} & \multirow[t]{2}{*}{619} & \multirow[t]{2}{*}{0.451} \\
\hline & Accredited & 3.98 & 2.0157 & & & \\
\hline \multirow[t]{2}{*}{ Professionalism } & Non-accredited & 4.14 & 0.9954 & \multirow[t]{2}{*}{-1.003} & \multirow[t]{2}{*}{619} & \multirow[t]{2}{*}{0.552} \\
\hline & Accredited & 4.23 & 1.3168 & & & \\
\hline \multirow[t]{2}{*}{ Staff Services } & Non-accredited & 4.20 & 0.7447 & \multirow[t]{2}{*}{-1.075} & \multirow[t]{2}{*}{618} & \multirow[t]{2}{*}{0.316} \\
\hline & Accredited & 4.29 & 1.2648 & & & \\
\hline \multirow[t]{2}{*}{ Medical Quality } & Non-accredited & 4.52 & 1.1895 & \multirow[t]{2}{*}{0.906} & \multirow[t]{2}{*}{619} & \multirow[t]{2}{*}{0.365} \\
\hline & Accredited & 4.44 & 0.9582 & & & \\
\hline Diagnostic Services & Non-accredited & 3.63 & 1.8519 & -2.441 & 619 & 0.015 \\
\hline
\end{tabular}




\begin{tabular}{|l|l|l|l|l|l|l|}
\hline & Accredited & 4.01 & 1.9916 & & & \\
\hline Patient Satisfaction & Non-accredited & 4.28 & 0.9478 & -0.051 & 619 & 0.959 \\
\cline { 2 - 5 } & Accredited & 4.28 & 0.9195 & & & \\
\cline { 1 - 5 } Accredited Hospital $(N=312)$ & \multicolumn{3}{|l|}{ Non-accredited Hospital (N=309) } \\
\hline
\end{tabular}

Patient Satisfaction $(M=4.28)$ and Admission Services $(M=4.27)$ get almost identical scores in both accredited and nonaccredited hospitals (see Table 3). The mean score of all the constructs of accredited hospitals is slightly higher than or equal to non-accredited except the 'Medical Quality' construct (Accredited $M=4.44 \pm 0.9582$; Non-accredited $M=4.52 \pm 1.8519)$. However, the mean difference is statistically significant only for 'Physical Facility' (t (619) $=-3.342, p=.001$ ), Patient Centeredness (t (619) $=-2.386$, $p=.017)$, Accessibility of Medical Services ( $(619)=-2.968, p=.003)$ and Diagnostic Services $(\mathrm{t}(619)=-2.441, \mathrm{p}=.015)$.

Table 4. Hypothesis testing - dimensions of quality healthcare delivery enhances patient satisfaction in accredited hospitals

\begin{tabular}{|c|l|c|l|}
\hline $\begin{array}{l}\text { Sl. } \\
\text { No }\end{array}$ & Hypothesis(N=309) & $\begin{array}{c}\text { Spearman's } \\
\text { rho }(r)\end{array}$ & -value \\
\hline 1 & Physical Facilities- Patient satisfaction & 0.702 & 0.000 \\
\hline 2 & Admission Services- Patient satisfaction & 0.506 & 0.000 \\
\hline 3 & Patient Centeredness- Patient satisfaction & 0.666 & 0.000 \\
\hline 4 & Accessibility of Treatment- Patient satisfaction & 0.706 & 0.000 \\
\hline 5 & Financial Matters- Patient satisfaction & 0.531 & 0.000 \\
\hline 6 & Professionalism- Patient satisfaction & 0.704 & 0.000 \\
\hline 7 & Staff Services- Patient satisfaction & 0.747 & 0.000 \\
\hline 8 & Medical Quality- Patient satisfaction & 0.703 & 0.000 \\
\hline 9 & Diagnostic Services- Patient satisfaction & 0.720 & 0.000 \\
\hline & \multicolumn{2}{|c|}{$\mathrm{p}<0.05 ; \mathrm{N}=312$} \\
\hline
\end{tabular}


medRxiv preprint doi: https://doi.org/10.1101/2020.08.22.20170837; this version posted August 25, 2020. The copyright holder for this preprint (which was not certified by peer review) is the author/funder, who has granted medRxiv a license to display the preprint in perpetuity.

It is made available under a CC-BY-NC-ND 4.0 International license .

The correlation analysis of the accredited hospitals indicated a significant positive association between patient satisfaction and the chosen constructs overarching various quality dimensions using Spearman's correlation Coefficient (see Table.4). Here, the dependent variable patient satisfaction is correlated significantly with Physical Facilities (Spearman's $\rho=.702 ; \mathrm{p}<0.05)$, Admission Services (Spearman's $\rho=.506 ; \mathrm{p}<0.05$ ), Patient Centeredness (Spearman's $\rho=.666 ; \mathrm{p}<0.05$ ), Accessibility of Treatment (Spearman's $\rho==.706 ; \mathrm{p}<0.05$ ), Financial Matters (Spearman's $\rho=.531 ; \mathrm{p}<0.05$ ), Professionalism (Spearman's $\rho=.704 ; \mathrm{p}<0.05$ ), Staff Services (Spearman's $\rho=.747 ; \mathrm{p}$ $<0.05$ ), Medical Quality (Spearman's $\rho=.703 ; \mathrm{p}<0.05)$ and Diagnostic Services (Spearman's $\rho=.720 ; \mathrm{p}<0.05$ ) and hence the above hypothesis is confirmed. However, the Kruskal-Wallis test indicated that there is no significant positive association between Accreditation and Patient Satisfaction $\left(\chi^{2}=3.857, \mathrm{p}<0.05\right)$.

\subsection{Type of accreditation (NABH vs. KASH)}

Table 5: Comparison of differences of mean scores of constructs between NABH and KASH accredited hospitals

\begin{tabular}{|l|l|l|c|c|c|c|}
\hline Constructs & $\begin{array}{l}\text { Type of the } \\
\text { Hospital }\end{array}$ & Mean & SD & t value & Df & p-value \\
\hline \multirow{2}{*}{ Physical Facility } & NABH & 4.15 & 0.59499 & -2.878 & 310 & 0.004 \\
\cline { 2 - 5 } & KASH & 4.48 & 1.4224 & & & \\
\hline Admission Services & NABH & 4.16 & 0.87199 & -3.072 & 298 & 0.002 \\
\cline { 2 - 4 } & KASH & 4.48 & 0.85507 & & & \\
\hline \multirow{2}{*}{ Patient Centeredness } & NABH & 4.47 & 0.95419 & 1.415 & 310 & 0.158 \\
\cline { 2 - 4 } & KASH & 4.31 & 0.80387 & & & \\
\hline \multirow{2}{*}{$\begin{array}{l}\text { Accessibility of } \\
\text { medical Services }\end{array}$} & NABH & 3.94 & 1.0983 & 0.335 & 310 & 0.738 \\
\cline { 2 - 4 } Financial Factors & KASH & 3.90 & 1.1235 & & & \\
\hline
\end{tabular}


medRxiv preprint doi: https://doi.org/10.1101/2020.08.22.20170837; this version posted August 25, 2020. The copyright holder for this preprint (which was not certified by peer review) is the author/funder, who has granted medRxiv a license to display the preprint in perpetuity.

It is made available under a CC-BY-NC-ND 4.0 International license .

\begin{tabular}{|c|c|c|c|c|c|c|}
\hline & $\mathrm{KASH}$ & 4.54 & 2.8545 & & & \\
\hline \multirow[t]{2}{*}{ Professionalism } & $\mathrm{NABH}$ & 4.24 & 1.5398 & \multirow[t]{2}{*}{0.253} & \multirow[t]{2}{*}{310} & \multirow[t]{2}{*}{0.800} \\
\hline & $\mathrm{KASH}$ & 4.20 & 0.74653 & & & \\
\hline \multirow[t]{2}{*}{ Staff Services } & $\mathrm{NABH}$ & 4.30 & 1.11094 & \multirow[t]{2}{*}{0.273} & \multirow[t]{2}{*}{310} & \multirow[t]{2}{*}{0.785} \\
\hline & $\mathrm{KASH}$ & 4.26 & 1.51584 & & & \\
\hline \multirow[t]{2}{*}{ Medical Quality } & $\mathrm{NABH}$ & 4.43 & 1.12193 & \multirow[t]{2}{*}{-0.269} & \multirow[t]{2}{*}{310} & \multirow[t]{2}{*}{0.788} \\
\hline & $\mathrm{KASH}$ & 4.46 & 0.53802 & & & \\
\hline \multirow[t]{2}{*}{ Diagnostic Services } & $\mathrm{NABH}$ & 3.91 & 0.88508 & \multirow[t]{2}{*}{-1.219} & \multirow[t]{2}{*}{310} & \multirow[t]{2}{*}{0.224} \\
\hline & $\mathrm{KASH}$ & 4.20 & 3.14696 & & & \\
\hline \multirow[t]{2}{*}{ Patient Satisfaction } & $\mathrm{NABH}$ & 4.27 & 0.67874 & \multirow[t]{2}{*}{-0.257} & \multirow[t]{2}{*}{310} & \multirow[t]{2}{*}{0.798} \\
\hline & $\mathrm{KASH}$ & 4.30 & 1.25417 & & & \\
\hline
\end{tabular}

For NABH hospitals, the mean score of only four constructs (Patient Centeredness, Accessibility of Medical Services, Professionalism and Staff Services) is higher (see Table 5). The mean score of five constructs (Physical Facility, Admission Services, Medical Quality, Financial Matters and Diagnostic Services) is higher in KASH accredited hospitals. Again, it shows that the differences were statistically not significant for six constructs (Patient Centeredness, Accessibility of medical Services, Professionalism, Staff Services, Medical Quality and Diagnostic Services). The mean score of the construct 'Patient Satisfaction' in NABH accredited hospital $(M=4.27 \pm 0.67874)$ is lower than that of $\mathrm{KASH}$ accredited hospital $(\mathrm{M}=4.30 \pm 1.25417)$ even though the difference is statistically not significant $(\mathrm{t}(310)=-.257, \mathrm{p}=.798)$.

\section{DISCUSSION}

This study was conducted with the aim of examining the dimensions of quality healthcare delivery in accredited public healthcare institutions in Kerala. The analysis did not show 
medRxiv preprint doi: https://doi.org/10.1101/2020.08.22.20170837; this version posted August 25, 2020. The copyright holder for this preprint (which was not certified by peer review) is the author/funder, who has granted medRxiv a license to display the preprint in perpetuity.

It is made available under a CC-BY-NC-ND 4.0 International license .

any significant difference in patient satisfaction between accredited and non-accredited hospitals. Satisfaction is an expression of the patients' overall judgment on the quality of care, including interpersonal aspects (Donabedian, 1980) and 'how well' the services provided to meet their needs and expectations (Haj-Ali et al., 2014). This study is validated by many earlier studies (Greenfield et al., 2008; Haj-Ali et al., 2014; Hayati et al., 2010; Heuer, 2004; Sack et al., 2010; Sack et al., 2011). However, the present study establishes that quality is marginally enhanced due to accreditation process.

Planned comparisons revealed that $\mathrm{KASH}$ accreditation has more impact on quality healthcare delivery and patient satisfaction which ties well with the previous study, wherein Lam et al., (2018) could not observe better patient experience at $\mathrm{JCl}$ accredited hospitals, and satisfaction was slightly worse compared with the level of satisfaction at state survey hospitals. The same study result was obtained by them over the consecutive years (2014 and 2015). This result is also congruent with the study of Greenfield \& Braithwaite( 2009) who found that organisations with different levels of accreditation, the performance showed varied rates of improvement. It is worth discussing the interesting fact that a contradictory result has been obtained in the case of healthcare dimension constructs of $\mathrm{NABH}$ and $\mathrm{KASH}$, where $\mathrm{NABH}$ is a higher-order national level accreditation system. Patient satisfaction is lower in $\mathrm{NABH}$ than $\mathrm{KASH}$, and that raises questions about the implementation of $\mathrm{NABH}$ programme, a long-drawn expensive process requiring many inspections over a period of three to five years.

Physical Facility and Diagnostic Services are significantly improved as the accreditation process largely focuses on infrastructure development (Haj-Ali et al., 2014; Sack et al., 2011). Accreditation eased doctor consultation and patient-doctor communication which 
medRxiv preprint doi: https://doi.org/10.1101/2020.08.22.20170837; this version posted August 25, 2020. The copyright holder for this preprint (which was not certified by peer review) is the author/funder, who has granted medRxiv a license to display the preprint in perpetuity.

It is made available under a CC-BY-NC-ND 4.0 International license .

is an important concern in hospital choice. However, accreditation could not bring remarkable changes in other areas requiring humane approach, therefore, not impacted in patient satisfaction. In addition, patients do not get any added financial advantage while seeking healthcare from an accredited public healthcare facility. This is not something to ignore when $42.25 \%$ of the population depends on public facility due to their financial insecurities, $69.4 \%$ belongs to $<R s .5000$ income group and $66.85 \%$ are from the venerable section of the society (women, koolies (daily workers), and students) (Refer, Table.2). Maya (2016) noted that the costs of one hospitalisation episode (in-patient) in the private sector in Kerala is Rs.22, 989, which is 200 percent higher when compared to the costs in the public sector, Rs.11,065. The cost of an outpatient visit in the private sector is Rs.525, which was Rs.391 in the public sector. Obviously, it is crucial to strengthen the public sector when the overall healthcare costs in Kerala remain high.

The study results are steady with the earlier studies(Greenfield \& Braithwaite, 2009; Sack et al., 2011; van Doorn - Klomberg et al., 2014) that hospital accreditation is not necessarily a contributor for quality care even though it has a reflection total quality enhancement. Further, these results go against the primary focus of the Twelfth Five Year Plan of Kerala (2012-17), which was quality care. However, the study shows that accreditation programs can facilitate continual and systematic improvement to hospitals sub-systems (Greenfield et al., 2019). It is important to recall the observation of WHO (2019, p.227) that despite the amount of money invested in the implementation of accreditation programs, evidence on cost-effectiveness is almost non-existent. To this end, Lam et al., (2018,p.227) suggested that "If we are to continue to use accreditation and spend the substantial sums of money they require - then we should consider 
medRxiv preprint doi: https://doi.org/10.1101/2020.08.22.20170837; this version posted August 25, 2020. The copyright holder for this preprint (which was not certified by peer review) is the author/funder, who has granted medRxiv a license to display the preprint in perpetuity.

It is made available under a CC-BY-NC-ND 4.0 International license .

substantially rethinking our accreditation process." In this context, all quality enhancement program must ensure the attainment of fundamental goals of health systems for health improvement and responsiveness to legitimate expectations of the patients (WHO, 2000) while ensuring cost-effectiveness. Viewing the successful Kerala healthcare model in preventing the epidemic outbreaks with its organised three tier public healthcare system, Kerala can upgrade its public health facilities qualitatively and quantitatively with an additional financial healthcare allocation and making use of Kerala's dedicated and efficient healthcare workers.

The results demonstrate three major findings. First, accreditation is not an essential tool for bringing a remarkable improvement in quality healthcare delivery and, thereby, patient satisfaction. Second, accreditation can enhance the quality only through the sufficient allocation of funds, employing adequate and professional human resource(Yousefinezhadi et al., 2020), providing free treatment including diagnostic tests, adopting personalised approach through the effective implementation of the accreditation program. Third, Kerala healthcare institutions may favor KASH accreditation as an initial step towards quality enhancement than the national level NABH accreditation.

The data was collected at the same period of Nipah outbreak (2018 May)which caused geographical limitations and denial in accessing in-patients. To truly assess the impact of accreditation, the study requires more data from the same strata and, therefore, future research should further confirm these initial findings by including all accredited hospitals under study. 
medRxiv preprint doi: https://doi.org/10.1101/2020.08.22.20170837; this version posted August 25, 2020. The copyright holder for this preprint (which was not certified by peer review) is the author/funder, who has granted medRxiv a license to display the preprint in perpetuity.

\section{CONCLUSION}

The evidence from the current study suggests that there is no significant impact of accreditation on patient satisfaction. Nevertheless, the different dimensions of healthcare are marginally improved through the accreditation process. As a step towards quality enhancement, accreditation programme should be monitored effectively to get the best results. Overall, these results suggest that it is vital to train and motivate all healthcare workers with an attitude of patient-centeredness, work efficiency, better recognition of patient's needs with promptness, bridging the communication gap between the caregivers and patients for effective healthcare delivery.

\section{Author Statements}

\section{Ethical approval}

The entire study was conducted in accordance with the guidelines and ethical approval received from the Department of Health, Government of Kerala and the Indian Council for Social Science Research (ICSSR). Informed consent was obtained from the respondents before collecting their data. A prior written permission was also obtained from the Directorate of Health Services, Kerala to access in-patients in medical wards.

\section{Funding}

This work was supported by grants from the Indian Council for Social Science Research (ICSSR), Government of India (F.No.02/349/2016-17/RP). 


\section{REFERENCES}

Al Otaibi, AM, Kattan, WM, Nabil, A. (2020). The Impact of Saudi (CBAHI) Accreditation on Enhancing Patient Safety and Improving the Quality of Care Indicators. Prensa Med Argent, 106, 3.

Al Tehewy, M., Salem, B., Habil, I., \& El Okda, S. (2009). Evaluation of accreditation program in non-governmental organisations' health units in Egypt: short-term outcomes. International Journal for Quality in Health Care, 21(3), 183-189. https://doi.org/10.1093/intqhc/mzp014

Almoajel, A. M. (2012). Relationship between accreditation and quality indicators in hospital care: A review of the literature. World Applied Sciences Journal, 17(5), 59806.

Amin, M, Nasharuddin, Z. (2013). Hospital service quality and its effects on patient satisfaction and behavioural intention. Clinical Governance: An International Journal, 18(3), 238-254.

Andres, E. B., Song, W., Song, W., \& Johnston, J. M. (2019). Can hospital accreditation enhance patient experience? Longitudinal evidence from a Hong Kong hospital patient experience survey. BMC Health Services Research, 19(1), 623. https://doi.org/10.1186/s12913-019-4452-z

Banyai, M. (2012). Assessing visitors' satisfaction at parks Canada sites. University of Waterloo.

Bogh, S. B., Falstie-Jensen, A. M., Bartels, P., Hollnagel, E., \& Johnsen, Sø. P. (2015). Accreditation and improvement in process quality of care: a nationwide study. 
medRxiv preprint doi: https://doi.org/10.1101/2020.08.22.20170837; this version posted August 25, 2020. The copyright holder for this preprint (which was not certified by peer review) is the author/funder, who has granted medRxiv a license to display the preprint in perpetuity. It is made available under a CC-BY-NC-ND 4.0 International license.

International Journal for Quality in Health Care, 27(5), 336-343. https://doi.org/10.1093/intqhc/mzv053

Camillo, N. R. S., Oliveira, J. L. C. de, Bellucci Junior, J. A., Cervilheri, A. H., Haddad, M. do C. F. L., \& Matsuda, L. M. (2016). Acreditação em hospital público: percepções da equipe multiprofissional. Revista Brasileira de Enfermagem, 69(3), 451-459. https://doi.org/10.1590/0034-7167.2016690306i

Cheng, S.-H. (2003). Patient satisfaction with and recommendation of a hospital: effects of interpersonal and technical aspects of hospital care. International Journal for Quality in Health Care, 15(4), 345-355. https://doi.org/10.1093/intqhc/mzg045

Darwazeh, D. (2011). Medical Tourism: Establishing a Sustainable Medical Facility. University of Waterloo.

Delgoshaei, B, Ravaghi, H, Abolhassani, N. (2012). IPA of medical tourism in Iran from medical tourists and medical service provider's perspective: 2011. Middle-East Journal of Scientific Research, 12(11), 1541-1547.

Despotou, G., Her, J., \& Arvanitis, T. N. (2020). Nurses' Perceptions of Joint Commission International Accreditation on Patient Safety in Tertiary Care in South Korea: A Pilot Study. Journal of Nursing Regulation, 10(4), 30-36. https://doi.org/10.1016/S21558256(20)30011-9

Donabedian, A. (1980). The Definition of Quality and Approaches to Its Assessment. Vol 1. Explorations in Quality Assessment and Monitoring. In Ann Arber, MI, Health Administration Press. 
medRxiv preprint doi: https://doi.org/10.1101/2020.08.22.20170837; this version posted August 25, 2020. The copyright holder for this preprint (which was not certified by peer review) is the author/funder, who has granted medRxiv a license to display the preprint in perpetuity. It is made available under a CC-BY-NC-ND 4.0 International license .

Elleuch, A. (2008). Patient satisfaction in Japan. International Journal of Health Care Quality Assurance, 21(7), 692-705. https://doi.org/10.1108/09526860810910168

Greenfield, D., \& Braithwaite, J. (2009). Developing the evidence base for accreditation of healthcare organisations: a call for transparency and innovation. Quality and Safety in Health Care, 18(3), 162-163. https://doi.org/10.1136/qshc.2009.032359

Greenfield, D., Braithwaite, J., \& Pawsey, M. (2008). Health care accreditation surveyor styles typology. International Journal of Health Care Quality Assurance, 21(5), 435443. https://doi.org/10.1108/09526860810890422

Greenfield, D., Lawrence, S. A., Kellner, A., Townsend, K., \& Wilkinson, A. (2019). Health service accreditation stimulating change in clinical care and human resource management processes: A study of 311 Australian hospitals. Health Policy, 123(7), 661-665. https://doi.org/10.1016/j.healthpol.2019.04.006

Grewal, I., Das, J. K., \& Kishore, J. (2012). Concerns, expectations and satisfaction of medical tourists attending tertiary care hospitals in New Delhi, India. Journal International Medical Sciences Academy, 25(3), 151-154.

Gursoy, D., \& Rutherford, D. G. (2004). Host attitudes toward tourism. Annals of Tourism Research, 31(3), 495-516. https://doi.org/10.1016/j.annals.2003.08.008

Haj-Ali, W., Bou Karroum, L., Natafgi, N., \& Kassak, K. (2014). Exploring the relationship between accreditation and patient satisfaction - the case of selected Lebanese hospitals. International Journal of Health Policy and Management, 3(6), 341-346. https://doi.org/10.15171/ijhpm.2014.116 
medRxiv preprint doi: https://doi.org/10.1101/2020.08.22.20170837; this version posted August 25, 2020. The copyright holder for this preprint (which was not certified by peer review) is the author/funder, who has granted medRxiv a license to display the preprint in perpetuity.

It is made available under a CC-BY-NC-ND 4.0 International license .

Hayati, N, Azimatun, NA, Rozita, H, Sh Ezat, WA, Rizal, A. (2010). In-patients' satisfaction in the medical and surgical wards - a comparison between accredited and non accreditated hospital in the State of Selangor. Malaysian Journal of Community Health, 16(1), 60-68.

Heuer, A. J. (2004). Hospital Accreditation and Patient Satisfaction. Journal For Healthcare Quality, 26(1), 46-51. https://doi.org/10.1111/j.19451474.2004.tb00471.x

Joseph, S. (2012). Role of allopathic and ayurvedic systems in Kerala tourism development (Minor Research Report). http://gpmgcollege.in/executive summary.pdf

Joseph, S. (2016). Development of sustainable indicators for medical tourism development in Kerala with reference to modern medicine [Kottayam: Mahatma Gandhi University]. http://hdl.handle.net/10603/184561

Joseph, S. (2017). Sustainable medical tourism model - A case study of Kerala, India. Asia-Pacific Journal of Innovation in Hospitality and Tourism, 6(1), 77-98.

Kang, E.-J., Scott, N., Lee, T. J., \& Ballantyne, R. (2012). Benefits of visiting a 'dark tourism' site: The case of the Jeju April 3rd Peace Park, Korea. Tourism Management, 33(2), 257-265. https://doi.org/10.1016/j.tourman.2011.03.004

Kavitha, R. (2012). A Comparative Study on Patients' Satisfaction in Health care Service. European Journal of Business and Management, 4(13), 156-159.

Kerala State Planning Board. (2017). Economic Review. 
medRxiv preprint doi: https://doi.org/10.1101/2020.08.22.20170837; this version posted August 25, 2020. The copyright holder for this preprint (which was not certified by peer review) is the author/funder, who has granted medRxiv a license to display the preprint in perpetuity. It is made available under a CC-BY-NC-ND 4.0 International license .

http://spb.kerala.gov.in/ER2017/web_e/ch421.php

Lam, M. B., Figueroa, J. F., Feyman, Y., Reimold, K. E., Orav, E. J., \& Jha, A. K. (2018). Association between patient outcomes and accreditation in US hospitals: observational study. BMJ, 363, k4011. https://doi.org/10.1136/bmj.k4011

Lam, S. S. K. (1997). SERVQUAL: A tool for measuring patients' opinions of hospital service quality in Hong Kong. Total Quality Management, 8(4), 145-152. https://doi.org/10.1080/0954412979587

Legido-Quigley, H., McKee, M., Nolte, E., \& Glinos, I. A. (2008). Assuring the Quality of Health Care in the European Union: A Case for Action (No.12). In Copenhagen: WHO Regional Office for Europe.

Lin, H.-C. (2004). Patient perceptions of service quality in group versus solo practice clinics. International Journal for Quality in Health Care, 16(6), 437-445. https://doi.org/10.1093/intqhc/mzh072

Linder-Pelz, S. (1982). Toward a theory of patient satisfaction. Social Science \& Medicine, 16(5), 577-582. https://doi.org/10.1016/0277-9536(82)90311-2

Maya, C. (2015, January 28). Govt. hospitals to go in for quality certification. The Hindu. https://www.thehindu.com/news/cities/Thiruvananthapuram/govt-hospitals-to-go-infor-quality-certification/article6828708.ece

Maya, C. (2016, May 12). Public health expenditure high in State. The Hindu. https://www.thehindu.com/news/cities/Thiruvananthapuram/public-healthexpenditure-high-in-state/article8588010.ece 
medRxiv preprint doi: https://doi.org/10.1101/2020.08.22.20170837; this version posted August 25, 2020. The copyright holder for this preprint (which was not certified by peer review) is the author/funder, who has granted medRxiv a license to display the preprint in perpetuity. It is made available under a CC-BY-NC-ND 4.0 International license .

Mondoux S, Calder-Sprackman S, Thull-Freedman J, C. L. (2020). CJEM to create a dedicated section for Quality Improvement and Patient Safety publication. Canadian Journal of Emergency Medicine, 22(1), 11-13.

Mosadeghrad, A. (2012). A Conceptual Framework for Quality of Care. Materia Socio Medica, 24(4), 251. https://doi.org/10.5455/msm.2012.24.251-261

Mosadeghrad, M. (2014). Patient choice of a hospital: implications for health policy and management. International Journal of Health Care Quality Assurance , 27(2), 152164.

National Rural Health Mission. (2013). Kerala Accreditation Standards for Hospitals (Second Edition).

Newcomer, L. N. (1997). Measures of Trust in Health Care. Health Affairs, 16(1), 50.

Pai, Y. P., \& Chary, S. T. (2016). Measuring patient-perceived hospital service quality: a conceptual framework. International Journal of Health Care Quality Assurance, 29(3), 300-323. https://doi.org/10.1108/IJHCQA-05-2015-0069

Parasuraman, A., Zeithaml, V. A., \& Berry, L. L. (1985). A Conceptual Model of Service Quality and Its Implications for Future Research. Journal of Marketing, 49(4), 41. https://doi.org/10.2307/1251430

Peprah, A. (2014). Determinants of Patients' Satisfaction at Sunyani Regional Hospital, Ghana. International Journal of Business and Social Research, 4(1), 96-108. https://doi.org/10.18533/ijbsr.v4i1.359

Pomey MP, Francois P, Contandriopoulos AP, Tosh A, B. D. (2005). Paradoxes of French 
medRxiv preprint doi: https://doi.org/10.1101/2020.08.22.20170837; this version posted August 25, 2020. The copyright holder for this preprint (which was not certified by peer review) is the author/funder, who has granted medRxiv a license to display the preprint in perpetuity. It is made available under a CC-BY-NC-ND 4.0 International license.

accreditation. BMJ Quality \& Safety, 14(1), 51-55.

Powell, L. (2001). Patient satisfaction surveys for critical access hospitals (Tech. Rep).

Rosenberg, B. L., Kellar, J. A., Labno, A., Matheson, D. H. M., Ringel, M., VonAchen, P., Lesser, R. I., Li, Y., Dimick, J. B., Gawande, A. A., Larsson, S. H., \& Moses, H. (2016). Quantifying Geographic Variation in Health Care Outcomes in the United States before and after Risk-Adjustment. PLOS ONE, 11(12), e0166762. https://doi.org/10.1371/journal.pone.0166762

Sack, C., Scherag, A., Lutkes, P., Gunther, W., Jockel, K.-H., \& Holtmann, G. (2011). Is there an association between hospital accreditation and patient satisfaction with hospital care? A survey of 37000 patients treated by 73 hospitals. International Journal for Quality in Health Care, 23(3), 278-283. https://doi.org/10.1093/intqhc/mzr011

Sack, Cornelia, Lütkes, P., Günther, W., Erbel, R., Jöckel, K.-H., \& Holtmann, G. J. (2010). Challenging the holy grail of hospital accreditation: A cross sectional study of in-patient satisfaction in the field of cardiology. BMC Health Services Research, 10(1), 120. https://doi.org/10.1186/1472-6963-10-120

Saeed, A. A., \& Mohamed, B. A. (2002). Patients' perspective on factors affecting utilisation of primary health care centers in Riyadh, Saudi Arabia. Saudi Medical Journal, 23, 1237-1242.

Saunders, M., Lewis, P., \& Thornhill, A. (2009). Research methods for business students. Fitfth Edition. In Pearson Education, UK. 
medRxiv preprint doi: https://doi.org/10.1101/2020.08.22.20170837; this version posted August 25, 2020. The copyright holder for this preprint (which was not certified by peer review) is the author/funder, who has granted medRxiv a license to display the preprint in perpetuity. It is made available under a CC-BY-NC-ND 4.0 International license .

Saxena, M. (2009). A Study on the Customer Perceptions of Quality of Services of a Large Hospital in New Delhi [Ghaziabad: Institute of Management Technology]. https://www.slideshare.net/mns2002/a-study-on-the-customer-perceptions-ofquality-of-services-of-a-large-hospital-in-new-delhi-2358778

Schmaltz, S. P., Williams, S. C., Chassin, M. R., Loeb, J. M., \& Wachter, R. M. (2011). Hospital performance trends on national quality measures and the association with joint commission accreditation. Journal of Hospital Medicine, 6(8), 454-461. https://doi.org/10.1002/jhm.905

Shaikh, Z. (2017). The impact of hospital accreditation on the patient's satisfaction of pharmacy department services. International Journal of Business, Management and Allied Sciences, 4(4), 10-16.

Solayappan, A., Jayakrishnan, J., \& Velmani, S. (2011). Quality Measurement for Hospital Services. International Conference on Information and Financial Engineering (Vol. 12).

Spasojevic, M, Susic, V. (2011). Development perspectives of new destinations in medical tourism. International Journal of Business Management and Social Sciences, 2(3), 9-13.

Tashkandi, FS, Hejazi, LO, Lingawi, H. (2017). Patients' Satisfaction with Dental Care Services Provided by Educational Dental Hospit. International. Journal of Health Sciences and Research, 6(7), 135-142.

van Doorn - Klomberg, A. L., Braspenning, J. C. C., Wolters, R. J., Bouma, M., \& Wensing, M. (2014). Effect of accreditation on the quality of chronic disease management: a 
medRxiv preprint doi: https://doi.org/10.1101/2020.08.22.20170837; this version posted August 25, 2020. The copyright holder for this preprint (which was not certified by peer review) is the author/funder, who has granted medRxiv a license to display the preprint in perpetuity. It is made available under a CC-BY-NC-ND 4.0 International license .

comparative observational study. BMC Family Practice, 15(1), 179. https://doi.org/10.1186/s12875-014-0179-4

Verlinde, E., De Laender, N., De Maesschalck, S., Deveugele, M., \& Willems, S. (2012). The social gradient in doctor-patient communication. International Journal for Equity in Health, 11(1), 12. https://doi.org/10.1186/1475-9276-11-12

Ware, J. E., Snyder, M. K., Wright, W. R., \& Davies, A. R. (1983). Defining and measuring patient satisfaction with medical care. Evaluation and Program Planning, 6(3-4), 247-263. https://doi.org/10.1016/0149-7189(83)90005-8

WHO. (2000). The world health report 2000 - Health systems: improving performance. Bulletin of the World Health Organization, 78(8), 1064. https://doi.org/10.1590/S0042-96862000000800020

Williams, S. C., Morton, D. J., Braun, B. I., Longo, B. A., \& Baker, D. W. (2017). Comparing Public Quality Ratings for Accredited and Nonaccredited Nursing Homes. Journal of the American Medical Directors Association, 18(1), 24-29. https://doi.org/10.1016/j.jamda.2016.07.025

World Health Organization. (2003). Guidelines for Safe Recreational Water. Volume 1. Coastal and Fresh Waters. In Geneva.

World Health Organization. (2019). Improving healthcare quality in Europe: characteristics, effectiveness and implementation of different strategies.

Yeoh, E., Othman, K., \& Ahmad, H. (2013). Patient-Centeredness Communication Strategy for the Medical Tourism Industry. Journal of Tourism Research \& 
Hospitality, 02(02). https://doi.org/10.4172/2324-8807.1000113

Yousefinezhadi, T., Mosadeghrad, A. M., Hinchcliff, R., \& Akbari-Sari, A. (2020). Evaluation results of national hospital accreditation program in Iran: The view of hospital managers. Journal of Healthcare Quality Research, 35(1), 12-18. https://doi.org/10.1016/j.jhqr.2019.08.008

Zineldin, M. (2006). The quality of health care and patient satisfaction. International Journal of Health Care Quality Assurance, 19(1), 60-92. https://doi.org/10.1108/09526860610642609 